Journal of Business and Tourism

Volume 06 Number 01

January - June, 2020

\title{
Vertical Integration and Outsourcing Decision Impact On Firm Performance: A Review Based Research on the Influence of Organizational Governance On firm Performance.
}

\author{
Sikandar Shah \\ MS Scholar, Institute of Business Studies and Leadership \\ Abdul Wali Khan University Mardan \\ Dr. Wisal Ahmad \\ Assistant Professor, Institute of Business Studies and Leadership \\ Abdul Wali Khan University Mardan \\ Dr. Muhammad Faizan Malik \\ Assistant Professor, Institute of Business Studies and Leadership \\ Abdul Wali Khan University Mardan \\ Shah Raza Khan \\ IQRA National University, Peshawar
}

\begin{abstract}
This studyexamines that how companies take decision of outsourcing and vertical integration a value-chain activity currently the most complex problem faced by most the organization around the globe and also find the relationship and highlight the role of every activity related to outsourcing and vertical integration. In result of survey and interviews of different small, medium and corporate level companies in KPK, procurement managers and operations managers mostly in view of that outsourcing is thebest way to work in the market, because of the cost reduction, minimumturnaround time and especially in the uncertain market of KPK.
\end{abstract}

KEYWORDS: Vertical Integration, outsourcing, Performance, transactioncost, Decision Making, Competition, Khyber Pakhtunhuwa.

\section{Introduction}

Every organization and business in the present highly competitive era wants to be most successful and have desire to get competitive edge in the market. Organizations either small in size or corporate level organization focuses on how to increase their performance and the most efficient in using different strategies. The most controversial problem in the current era for the organizations to be the market leaders is the innovations in the products but behind the scene of innovation firms faces thechallenge to shape their value chain activities and distribution channels by using outsourcing and vertical integration. To challenge these limitations a significant and direct relationship should be shaped and sustained between outsourcing and vertical integration. Strategists in the recent use different ways to create an effective strategy as compare to the future because of the awareness of the customers and advancement of technology. By the way of outsourcing and vertical integration the firm creates their degree of competitive advantage which leads to better performance as compare to the past and also with competitors. 
The intense dynamics of competition and the disintegration of the companies have provided great opportunity and directions for other companies to adopt the measures which will guarantee continuous and successful business operations.Kotler and Keller (2014) explained that firms in a highly competitive volatile environment will survive, by considering incorporated sales and profit growth as there major objectives. On the other hand, the lack of the same strategies can leads to loss of its entrepreneurial managers, responsible for generating successful integration strategies.

Two groups of arguments have been elevated by studying literature. One describes benefits of outsourcing that outside the firm's boundaries a lot of specialist have been waiting to give their services to the firm, in this scenario performance is directly linked with the capability to recognize, isolate and resolve the definite type of independent issues. In these conditions contracting risks are lower, specialization is favored and outsourcing will increase the efficiency and effectiveness by permittingexpert suppliers from scale economies, some recent results are consistent with these arguments (Liebeskind, 1996). On the other hand arguments praising the disadvantage of vertical integration is the increase of transaction cost but also main benefit of vertical integration accept that the most valuable capabilities of vertically integrated firms is that the ability to provide enhanced information transfer and coordination between different departments.

Vertical integration is of two types backward or forward. Backward integration comprises firm's strategy in action in expanding for the purpose to close to raw materials, in the stages of production permitting a firm to control the dimension and quality of the supplies being purchased. On the other hand, forward integration terms to the firm entering into the business of distributing or selling the present product and moving upwards in the production/distribution process towards the consumer (Hunger \& Wheelen, 2003). Forward integration occurs when firms moves closer to the end users in the of production stages, by allowing such firms more control over how the products and service are distributed and sold to the markets. Sometimes, the firm established its own distribution outlets for the sale of its own product.

Value chain activities are the lifeblood of every organization. It is of utmost importance to procurecorrectmaterialsfrom the suppliers and to utilize them effectively and efficiently. Mahoney (1992)proposes that the aims for vertical integration might be categorized into the four major, transaction cost considerations, strategic considerations, output and/or input price advantages and uncertainties in costs and/or prices.Every single company enters in vertical integration relation attempts to control its need of certainty. If the competitive conditions and demand variance become too opposed for it to tolerate, the company will be in strict pressure to change its strategy from vertical integration and start outsourcing.

Outsourcing also favored if the business lacksthe ability of bargaining which isessential to gain concessions from distributors and suppliers, and if the industry is increasingly instable, then the vertical integration strategy may not work as desired by the firm. According to strategists if the firm cannot survive the degree of powerful competition, it should start to redesign its vertical structure from the start as soon as possible or ready to exit from the competition. Moreover, the firms which able to restructure its vertical integration relationships will minimize its exit barriers (Harrigan \& Porter, 1989). 


\section{Literature Review}

The growing trend of purchasing inputs and other materials from outside suppliersgained more importance in the field of supply chain management. The same effected the integration process management of the firms which motivated managers to give more attention to suppliers-buyers relationship.But the next phase of unintegrated firm's shows that the outsourcing will only benefits for short term and in long term vertical integration strategies is more beneficial.Klein et al., (1978) found that an integrate firm can do better in the market rather than unintegrated firm if there are high profits involve in the value chain management by utilizing skills. Williamson (1979) clarified that uncertainty leads to more vertical integration because a supplier and distributor will demand complete long term contracts before committing to invest.Dierickx and Cool(1989) suggested that integration strategy might be essential for a business to collect resources for generation or maintaining a competitive benefit on other businesses.On the other hand Integration sometimes offer a firm a differentiation benefit as compare to other firms having unintegrated strategies (Caves et al., 1977).Conner and Prahalad(1996)also supported the same argument, explained that one source of differential performance among competitive firms is the way they establish exchange activity (Integration strategies).

For efficient management of the relationship with suppliers and buyers, firms have to select most relevant and beneficialrelationsstarting from purchasing till outputs distribution, and use strategies of management to maintain better and fit relationships (Bensaou,1999).The management of suppliers and buyers relationship is the key and popular research domain (Monczka et al., 1994; Tan, 001). Heide(1994) proposedthat outsourcing is a diverse terminology. According to their study different taxonomies and typologies developed from time to time in order to classify the relationships of buyer and suppliers.Lambert (1996) examined that the association with supplier can be started from arm's length to complete functional coordination. A perception from the various type of relationship perspective developed is the constructing and up surging performance which is the aim of every organization.

The governance strategy selected for the implementation of vertical integration is always selected to reduce the negotiating, adapting, monitoring and enforcing costs of buyer and supplier relationship cost e.g. cost saving from sales tax avoidance when arm's length diminishing is exchanged by internal transfers(Coase, 1937). More delicately, the petroleum companies having vertically integrated find a rise in their profits by increasing the price of crude oil as compare to the price of finish good in order to shift their most of earnings to raw materials extraction stage, which enjoys tax preferences connected with the depletion of resources (Bolch et al., 1978). Scherer et al., (1990)Scherer and Ross (1990) also explained that same outcomes can be found from the conversion of other industries also e.g. Copper, Aluminum and Steel.

Dyer and ouchi (1993), Helper et al., (1995);Mowery et al., (1996) suggests that outsourcing not only shifts cost from the local firms to suppliers, but also economic value within supply chain, allowing a firm to tap into specialized capabilities. Survey undertaken by the World Bank with thecooperation of Chinese enterprise survey organization in 2003. They distributed questionnaire to two levels of organization top management and senior accountant, personal manager focused on market condition, innovation, Marketing, suppliers, labor relations, ownership, varies financials measures and labor trainings. 18 cities were selected and random selection of 100-150 businesses from services and manufacturing industries completed. In result 2400 were surveyed with a question that how much percent of the spare parts etc. 
manufactured within the company premises. Among the firm managers are (less or more) aware of what type of parts is used in production process and what are outsourced. Gil(2009)examined a natural experiment in the Span to display that the distributors vertically integrated producesextraeffective decisions related to movie run length. David et al., (2013) studies on U.S health industry shows that the integrated firms produce better health outputs than unintegrated firms.

Adeleke and Onodugo (2019)concludedthat there were a limited number of strategic integration moves, most importantly the integration strategies.Therefore they are advised to enhance the personalization of their service to ensure that the existing customers remain locked in and new customers continue to be attracted.

\section{Figure 1: Research Framework}

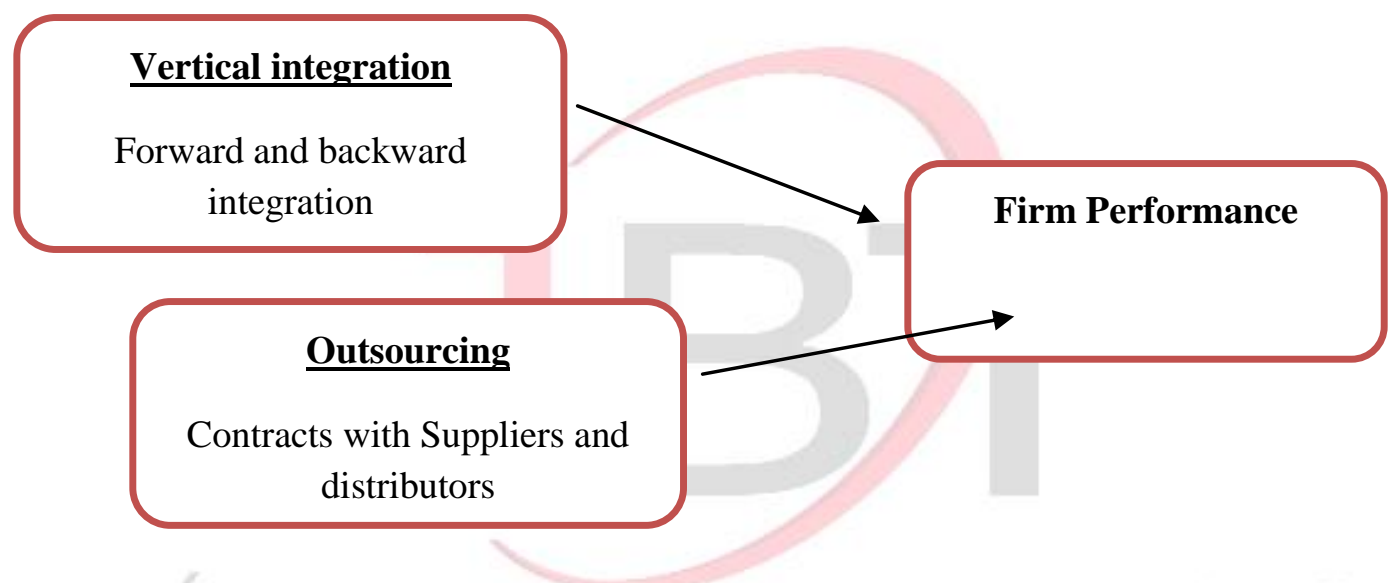

\section{Methodology}

Examination of the impacts of vertical integration and outsourcing on firm's performance has been conducted through the help of structured interviews from different procurement manager and operation manager of the companies working in KPK, the firms of the private sector working in KPK was specially targeted for the study because of their consistent behavior towards outsourcing as compare to vertical integration. Structure questions related to outsourcing and vertical integration impact on firm performance has been asked from all of them. As a result of their answers most of the managers suggested that outsourcing is the better way to perform in KPK as compare to other parts of Pakistan. The main idea behind outsourcing is that it reduces cost, time, focus on core business activities, selecting best supplier and distributor from the market and especially lower investment risk. Some of them also suggested Vertical integration strategy to be followed but the external factors in KPK like the border with Afghanistan is mostly closed due to unfavorable relationship of the both countries impact export to Afghanistan and other countries through Afghanistan. In this situation the performance of those companies who uses vertical integration goes down and the impact of which clearly provided by their financial statement e.g. sales declined.On the other hand in KPK vertical integration in reality is almost impossible because most of the companies tries to import from outside the country rather than becoming vertically integrated by gaining ownership or control over local suppliers and also hire specialized shipping companies or distributors for selling their finish good to other part of the country or for export to other countries. 


\subsection{The key factors of outsourcing success}

Outsourcing Institute of Membership given certain critical areas for the success of outsourcing in 1998 is appended:

- Firm goals and objectives

- Vision and mission

- Choosing the correct and high quality supplier

- Structuring properly the contract, effective contract and contract monitoring.

- Having good relationship with the supplier.

\subsection{Outsourcing Life Cycle}

The most commonly used process for outsourcing around the globe and also in KPK (Government, Contractors etc.)Outsourcing starts from strategic assessment of the company attitudes before initiation of a project. After assessment, the possible solution to be identified for outsourcing through need analysis. The third stage is the evaluation and choosing of vendor for outsourcing need identified. Vendors has been selected by giving tenders, quotation etc in different channels like newspapers and internet etc. once the vendor selection finished the next step is to start negotiation and made agreement of outsource work. The phase of project starting up and transition are the phases where the procurement departments are mostly involved. In this phases the complete materials are supplied to the sub-contractors and if any problem arises will resolved with the assistance of the total involved departments, the outsourcing relationship is shaped and the success till date and productivity of the process is analyzed by all the concerned departments. The main idea behind this phase is to update with the outsourcing relationship. The related activities containof appraisal of the relationship,problem identification and solution, communications management, knowledge management and processmanagement.

\section{Figure 2: Outsourcing lifecycle}

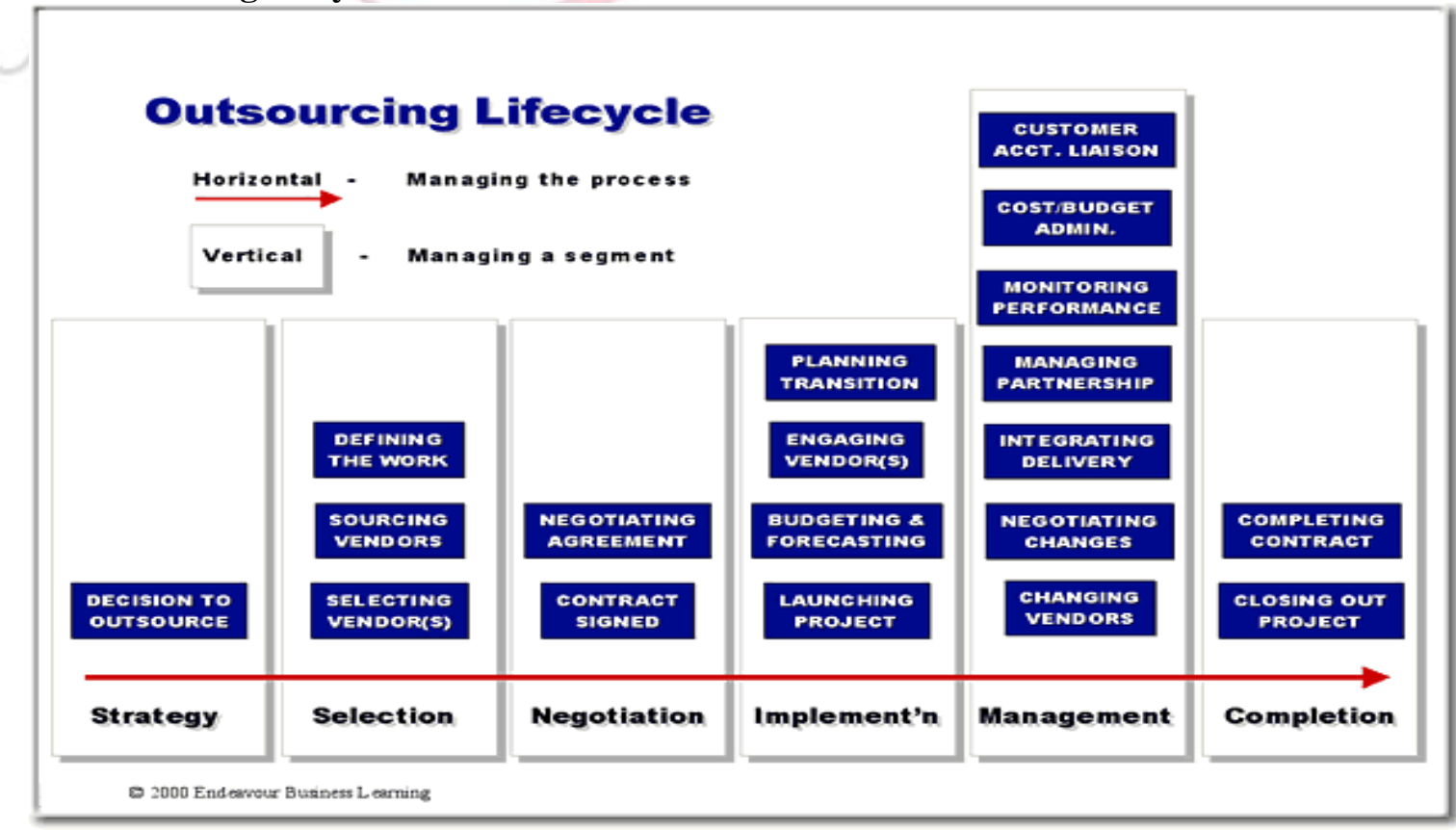




\subsection{Model for outsourcing:}

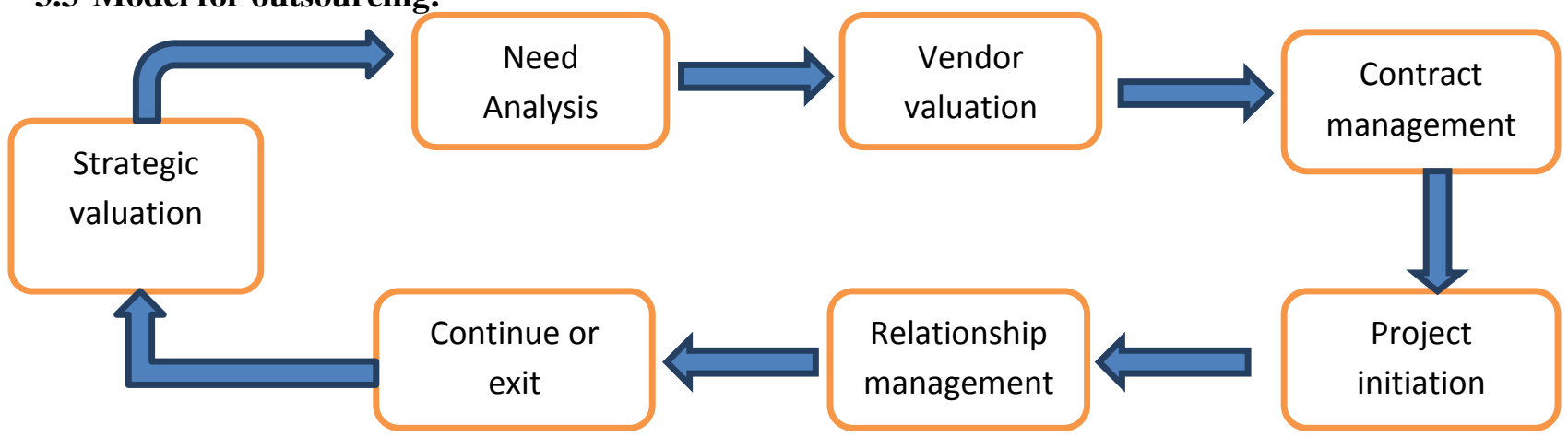

\section{Organizational outsourcing in terms of Labor}

In recent decade organizations of developed countries focused more on Outsourcing of labors and experts from developing countries rather than hiring from local market to reduce cost of wages paid. This brings very worst impact in long run on the organization performance and at the end either directly or indirectly impact local economy. If we look into the market of gulf countriesnational statistics shows that $49 \%$ of the whole population is foreigners. This shows outsourcing strategies importance for the host countries. But beside this as the key impacts of outsourcing is shown in the table below:

\begin{tabular}{|l|l|}
\hline Outsourcing impacts for local countries & Impact on Developing countries \\
\hline $\begin{array}{l}\text { Professional service workers losing jobs } \\
\text { because they become more expensive for the } \\
\text { companies }\end{array}$ & $\begin{array}{l}\text { Balance of payment through foreign salaries } \\
\text { increasing day by day. }\end{array}$ \\
\hline Firms hiring foreign labor & More chance of getting jobs easily \\
\hline $\begin{array}{l}\text { Required consultants in developing countries } \\
\text { which incur more cost. }\end{array}$ & $\begin{array}{l}\text { Firms established providing consultancy } \\
\text { services to local people for job hunting. }\end{array}$ \\
\hline Customers need professional services & Professional labor needs heavy returns. \\
\hline
\end{tabular}

\section{Conclusion}

Strategies play an important role on firm performance. Firms around the globe conducting seminars and brains storming techniques for the generation of strategies through collection of different ideas. The impact of these generated ideas in actions is then reflecting in the productivity of firms.

If the vertical integration and outsourcing strategies of a firm are favorable then the firms will become leader of the market in competition which will leads to heavy generation of cash flows and in long run firm performance will go upward. Hence top management has to consider these strategies as a competitive edge for smooth business and high performance in the competition. After comprehensive interviews from mangers of different businesses working in $\mathrm{KPK}$ it is concluded that outsourcing is the best strategy to use for organizational performance rather than vertical integration strategies. This is because first of all local market is unable to provide good quality material that's why firms don't want to involve in integration and prefer to outsource as much as possible through imports. Last year imports of different banks in KPK show how much companies relay on outsourcing rather than shifting to integration strategies. 


\subsection{Companies included}

\begin{tabular}{|l|l|}
\hline Premier Suger Mills limited & Khyber Tobacco Company limited \\
\hline Aries Pharma (Pvt) Limited & Frontier Leaf tobacco \\
\hline Stanley Pharmaceutical (Pvt.) Ltd & Stanlay Food (Pvt.) Limited \\
\hline A.J Textiles Limited & A.J Spinning Limited \\
\hline Bilour Industries limited & Royal Textiles Mills Limited \\
\hline Pak Hills T and R (Pvt) limited & SarhadCigratte (Pvt.) Limited \\
\hline Bacha Tyres Corporation & Universal Tobacco Company (Pvt) Limited \\
\hline Choice Cigreatte (SME) Pvt. Limited & Insaf Trading Co. \\
\hline Qazafi trading & Premier Formica and chipboard \\
\hline Peshawar Particle board & Sarhad Textile Mills Limited \\
\hline
\end{tabular}

\section{References}

Adeleke, B. S., \& Onodugo, V. A. (2019). Effect Of Forward Integration Strategy On Organizational Growth: Evidence From Selected Insurance And Banking Organizations In Nigeria. In Academy of Strategic Management Journal (Vol. 18, Issue 2).

Bolch, B. W. D.-S. E., (1978). The depletion allowance and vertical integration in the petroleum industry. JSTOR. Retrieved August 9, 2020, from https://www.jstor.org/stable/1057631

Caves, R., (1977). From entry barriers to mobility barriers: Conjectural decisions and contrived deterrence to new competition. JSTOR. Retrieved August 9, 2020, from https://www.jstor.org/stable/1885416

Conner, K. R., \& Prahalad, C. K. (1996). A Resource-based Theory of the Firm: Knowledge Versus Opportunism. Organization Science, 7(5), 477-501. https://doi.org/10.1287/orsc.7.5.477

David, G., Rawley, E., \& Polsky, D. (2013). Integration and task allocation: Evidence from patient care. Journal of Economics and Management Strategy, 22(3), 617-639. https://doi.org/10.1111/jems.12023

Dierickx, I., \& Cool, K. (1989). Asset Stock Accumulation and Sustainability of Competitive Advantage. Management Science, 35(12), 1504-1511. https://doi.org/10.1287/mnsc.35.12.1504

Dyer, J., O.-M. S. M., (1993). Japanese-style partnerships: giving companies a competitive edge. Search.Proquest.Com. Retrieved August 3, 2020, from http://search.proquest.com/openview/8c66c50e8d3d8d2390afd61472803e14/1?pqorigsite $=$ gscholar $\& \mathrm{cbl}=26142$

Gil, R. (n.d.). Revenue Sharing Distortions and Vertical Integration in the Movie Industry. Academic.Oup.Com. https://doi.org/10.1093/jleo/ewn004

Harrigan, K. R., \& Porter, M. E. (1989). End-game Strategies for Declining Industries. In Readings in Strategic Management (pp. 219-233). Macmillan Education UK. https://doi.org/10.1007/978-1-349-20317-8_16

Heide, J. B. (1994). Interorganizational Governance in Marketing Channels. Journal of Marketing, 58(1), 71-85. https://doi.org/10.1177/002224299405800106

Helper, S., M. S.-M. S. M., (1995). Supplier relations in Japan and the United States: are they converging? Search.Proquest.Com. Retrieved August 3, 2020, from http://search.proquest.com/openview/742d432776a5e55a48fbd7e98b95ea8f/1?pqorigsite $=$ gscholar $\& \mathrm{cbl}=26142$ 
Hunger, J., \& Wheelen, T. (2003). Essentials of Strategic Management. www.hrfolks.com

Klein, B., Crawford, R. G., \& Alchian, A. A. (1978). Vertical Integration, Appropriable Rents, and the Competitive Contracting Process. The Journal of Law and Economics, 21(2), 297 326. https://doi.org/10.1086/466922

Lambert, D. M. (1996). Article in The International Journal of Logistics Management. Researchgate.Net. https://doi.org/10.1108/09574099610805485

Liebeskind, J. P. (1996). Knowledge, strategy, and the theory of the firm. Strategic Management Journal, 17(SUPPL. WINTER), 93-107. https://doi.org/10.1002/smj.4250171109

Mahoney, J. T. (1992). The choice of organizational form: Vertical financial ownership versus other methods of vertical integration. Strategic Management Journal, 13(8), 559-584. https://doi.org/10.1002/smj.4250130802

Marketing management, (14th Edition) Kotler and Keller (2014) - Google Search. (n.d.). Retrieved August 3, 2020.

Monczka, R., Trent, R., I. J. (1993).. Supply base strategies to maximize supplier performance. Emerald.Com. Retrieved August 9, 2020, from https://www.emerald.com/insight/content/doi/10.1108/09600039310041509/full/html

Mowery, D. C., Oxley, J. E., \& Silverman, B. S. (1996). Strategic alliances and interfirm knowledge transfer. Strategic Management Journal, 17(SUPPL. WINTER), 77-91. https://doi.org/10.1002/smj.4250171108

Scherer, F. D. R.C. A.(1990). Industrial market structure and economic performance. Papers.Ssrn.Com. Retrieved August 9, 2020, from https://papers.ssrn.com/sol3/papers.cfm?abstract_id=1496716

Supply, K. T.-E. J. (2001). A framework of supply chain management literature. Elsevier. Retrieved August 9, 2020, from https://www.sciencedirect.com/science/article/pii/S0969701200000204

Williamson, O. E. (n.d.). Transaction-Cost Economics: The Governance Of Contractual Relations*. In journals.uchicago.edu. Retrieved August 9, 2020, from https://www.journals.uchicago.edu/doi/pdfplus/10.1086/466942 